Strukturasi Giddens dan Social Construction

\title{
STRUKTURASI GIDDENS DAN SOCIAL CONSTRUCTION OF TECHNOLOGY (SCOT) SEBAGAI PISAU ANALISIS ALTERNATIF PENELITIAN SOSIAL ATAS TEKNOLOGI MEDIA BARU
}

\author{
Adi Wibowo Octavianto \\ Program Studi Ilmu Komunikasi \\ Universitas Multimedia Nusantara \\ Jl. Boulevard, Gading Serpong Tangerang-Banten \\ Telpon (021) 54220808 \\ Email: adi.wibowo@umn.ac.id
}

\section{Abstrak}

Artikel ini menawarkan alternatif kerangka konseptual penelitian terhadap teknologi komunikasi semisal teknologi media baru. Kerangka konseptual yang ditawarkan menggunakan cara pandang paradigma konstruktivis dimana teknologi dipandang sebagai produk konstruksi sosial. Social Construction of Technology (SCoT) adalah konsep yang dikembangkan Pinch dan Bijker (1984). Seiring waktu SCoT mendapat perhatian dari akademisi-akademisi lain serta mengalami perkembangan dan modifikasi. Pada artikel ini penulis mencoba menyandingkan penggunaan SCoT dengan pendekatan agen-struktur dari teori strukturasi Giddens. Kerangka konsep tersebut telah dicobakan dalam penelitian penulis di tahun 2011. Teknologi yang diteliti adalah teknologi media sosial, sementara agen yang dimaksud adalah pengguna media sosial, kemudian budaya komunikasi ditempatkan sebagai struktur sosial yang berperan sebagai konteks yang lebih luas. Kerangka konseptual seperti dijelaskan di sini terutama bermanfaat untuk menguraikan hubungan teknologi dan masyarakat serta menjawab pertanyaan bagaimana proses saling membentuk terjadi antara teknologi dengan perilaku sosial dalam masyarakat.

Key words: Teknologi, Media Baru, Strukturasi, Social Construction of Technology, Konstruktivis, Giddens

\section{Teknologi dan Masyarakat}

Ilmuwan sosial cenderung melihat teknologi sebagai kesatuan terintegrasi antara aspek material dan non-material atau aspek teknis dan non-teknis. Read Bain menyebut- kan bahwa teknologi mencakup semua peralatan, mesin, instrumen, senjata dan sebagainya dan juga melibatkan keahlian kita dalam memproduksi dan menggunakannya (Bain, 1937). Rogers menjabarkan teknologi sebagai 
Strukturasi Giddens dan Social Construction of Technology (SCoT) Sebagai Pisau Analisis

Alternatif Penelitian Sosial Atas Teknologi Media

Baru

konsep yang terdiri dari komponen perangkat keras (hardware) dan perangkat lunak (software), dimana pengertian perangkat lunak digambarkan sebagai landasan informasi terkait dengan perangkat keras (Rogers, 1986). Perangkat lunak dalam definisi Rogers dapat juga diartikan sebagai serangkaian informasi mengenai makna teknologi dan cara menggunakan teknologi tersebut.

Berdasarkan cara pandang itu, maka kajian terhadap teknologi terutama dalam konteks ilmu sosial harus mempertimbangkan kedua aspek sekaligus, yaitu aspek material/ perangkat keras dan non-material/perangkat lunak. Suatu pertanyaan mendasar kajian teknologi dalam konteks ilmu sosial adalah mengenai makna teknologi bagi masyarakat dan bagaimana masyarakat merespon, menggunakan dan beradaptasi dengan kehadiran teknologi.

Sejauh ini berbagai referensi menunjukkan ada dua cara pandang utama terhadap kajian teknologi, yaitu determinasi teknologi (technological determinism) dan determinasi sosial (social determinism). Kaum determinasi teknologi berasumsi bahwa perkembangan teknologi adalah proses independen yang tidak berkaitan dengan proses-proses sosial, namun demikian setelah suatu teknologi terbentuk dan mengakar, maka teknologi itu akan memengaruhi penciptaan kondisi baru dalam masyarakat (Lievrouw \& Livistone, 2006b, p.4).

Sekitar tahun 1980-an pandangan determinasi teknologi mendapat tantangan dari kaum determinasi sosial yang kemudian menjadi pandangan dominan semenjak awal 1990-an (Lievrouw \& Livistone, 2006c, p.4). Menurut aliran determinasi sosial, munculnya inovasi dan teknologi merupakan bagian dari proses konstruksi sosial sehingga tidak bisa dilepaskan begitu saja dari proses-proses sosial disekitarnya. Teknologi dalam hal ini merupakan hasil bentukan sosial (social shaping). Maksud dari teknologi sebagai hasil bentukan sosial sebenarnya lebih kepada adanya hubungan timbal balik yang saling membentuk antara pengembangan teknologi dengan praktek-praktek sosial, sehingga antara teknologi dan praktek sosial sifatnya saling menentukan (co-determining) (Lievrouw \& Livistone, 2006b, p.4). Cara pandang seperti itu menurut Lievrouw dan Livistone membuat kajian terhadap teknologi harus memperhatikan dua aspek, yaitu; perhatian terhadap agensi dan tindakan, sekaligus pula menaruh perhatian pada efek-efek sosial, struktur dan dampak yang ditimbulkannya.

Munculnya pendekatan determinasi sosial tidak lepas dari perkembangan teori-teori sosial mengenai modernitas dan perubahan sosial, seperti teori mengenai ruang publik dari Habermas dan teori strukturasi dari Giddens. Teori-teori tersebut turut memberi inspirasi terhadap pendekatan teoretis baru yang mengaitkan teknologi khususnya media baru (new media) dengan struktur \& praktik sosial dalam hubungan yang saling menentukan (co-determination) (Lievrouw \& Livistone, 2006a, p.19). 


\section{Teknologi dan Budaya}

Pembahasan mengenai keterkaitan antara teknologi dan budaya telah dilakukan oleh beberapa ahli (Lievrouw \& Livistone, 2006b), (Krug, 2005a), (Flew, 2005). Krug bahkan menyarankan agar; diri (self), budaya dan teknologi dipandang sebagai elemen yang saling menciptakan dan saling merefleksikan, teknologi bahkan dapat dipandang sebagai suatu budaya (Krug, 2005, p.xi \& p.1-25).

Keberadaan suatu teknologi dapat merubah arah dunia sosial tempat masyarakat hidup. Teknologi dapat merubah persepsi dan pemikiran-pemikiran masyarakat tentang tatanan dunia. Namun sekali lagi ini tidak terjadi dalam konteks sesederhana determinasi teknologi, melainkan lahir melalui hubungan dialektis antara struktur-struktur makna dan ekpresi-ekpresi teknologi yang nyata. (Krug, 2005, p.19). Maka dari itu melakukan penelitian terhadap teknologi melalui perspektif budaya membutuhkan pendefinisian teknologi yang melingkupi tiga tingkat pendefinisian, yaitu; tidak hanya memahaminya sebatas obyek fisik, peralatan dan artefak; tapi juga dalam pengertian konten yang dihasilkan dan distribusikan; juga harus dilihat dalam konteks sistem pengetahuan dan makna sosial yang hadir bersamaan dengan penggunaan dan pengembangan teknologi itu (Flew, 2005, p.21).

Pemahaman tentang budaya menurut Flew juga harus diperluas bukan hanya sekedar dari dimensi artistik dan kreatif saja. Budaya harus dipahami sebagai suatu landasan sistem struktural (underlying structural sys- tem) atau sebagai suatu rangkaian matrix kode yang menjadi dasar diorganisasikannya aktivitas sosial. Budaya juga dapat dipahami sebagai keseluruhan cara hidup atau bentuk-bentuk pengalaman yang dijalani. Raymond Williams mendefinisikan budaya sebagai "a particular way of life" cara hidup tertentu yang dibentuk melalui sejumlah nilai tradisi, keyakinan, obyek material, dan wilayah. Lebih jauh Lull menyebutkan bahwa budaya adalah suatu konteks. Budaya adalah tentang cara memandang dunia dan menjalani berbagai aktivitas kehidupan, seperti misalnya cara berbahasa dan berpakaian (Lull, 1994, p.66). Pemahaman terakhir ini mengarahkan kita pada bentuk-bentuk nyata dari aktivitas komunikasi, hubungan sosial, dan praktek-praktek dalam kehidupan sehari-hari (Flew, 2005, p.26).

Berdasarkan level pendefinisian teknologi dan budaya tadi, kita dapat melihat ada titik temu antara teknologi dan budaya. Keterkaitan ini muncul manakala kita melihat teknologi sebagai sistem pengetahuan dan makna sosial yang hadir bersamaan dengan penggunaan teknologi. Pendefinisian tadi bersinggungan dengan definisi budaya sebagai landasan sistem struktural yang melaluinya aktivitas-aktivitas sosial diorganisasikan (Flew, 2005, p.26).

Titik temu inilah yang dimaksud Flew dan juga Krug saat mengatakan teknologi sebagai suatu bentuk budaya. Flew menamakan cara pandang ini sebagai cultural technologies atau teknologi yang bersifat budaya (Flew, 2005, p.28). Konsep ini sejalan pula dengan perspektif determinasi sosial sebagai 
Strukturasi Giddens dan Social Construction of Technology (SCoT) Sebagai Pisau Analisis

Alternatif Penelitian Sosial Atas Teknologi Media

Baru

suatu konsep yang berlawanan dengan perspektif determinasi teknologi. Flew mengutip Langdon untuk menggambarkan bagaimana konsep cultural technologies diterapkan untuk mengamati hubungan antara teknologi dan budaya. Langdon mengatakan teknologi bukan semata alat bantu bagi aktivitas manusia, namun merupakan kekuatan yang mendorong pembentukan ulang aktivitas-aktivitas tersebut dan maknanya.

Penelitian yang selaras dengan cara pandang teknologi dan budaya tersebut misalnya penelitian tentang teknologi media baru, yaitu media sosial yang dikaitkan dengan perkembangan atau perubahan budaya komunikasi seperti yang dilakukan Adi W. Octavianto (2011) atau penelitian terhadap perubahan budaya komunikasi dikalangan pengguna telpon genggam yang dilakukan oleh Brodjonegoro (2006).

\section{Struktur Giddens}

Seperti telah disebutkan sebelumnya perkembangan teori-teori sosial turut memberikan inspirasi bagi pendekatan teoretis baru dalam kajian terhadap teknologi, utamanya yang terkait dengan media baru (new media). Pendefinisian media baru sendiri selalu dikaitkan dengan teknologi komunikasi dan informasi (ICT's) yaitu yang biasa kita kenal dengan Internet (Flew, 2005) dan (Lievrouw \& Livistone, 2006a).

Teori strukturasi Giddens sangat layak dipertimbangkan sebagai kerangka konsep penelitian sosial atas teknologi mengingat perkembangan perspektif determinasi sosial yang menjadi trend dalam penelitian-penelitian seperti itu, banyak diinspirasikan oleh teori strukturasi Giddens (Liewrouw, 2006).

Anthony Giddens, penggagas teori strukturasi adalah seorang sosiolog Inggris. Pemikiran Giddens mengenai interplay antara struktur dan agensi dalam teori ini memiliki kesamaan dengan konsep co-determination antara perkembangan teknologi dan praktik-praktik sosial dalam perspektif determinasi sosial. Teori strukturasi Giddens pun menjadi inspirasi bagi Poole dan DeSantics (1990) dalam merumuskan Adaptive Structuration Theory (AST) (Hollingshead \& Contractor, 2006, p.123). AST mengajukan axiom yang menyebutkan bahwa struktur-struktur sosial dan tindak komunikasi (communicative action) itu saling merubah satu sama lain (Djik, 2006, p.17). Pada bagian lain Dijk (2006, p.242) juga menyebutkan struktur-struktur tersebut akan muncul dalam tindak komunikasi yang terjadi.

Pengaruh Giddens yang cukup besar dalam wacana teknologi dan masyarakat inilah yang mendorong penulis mencoba menawarkan landasan pemikiran strukturasi Giddens untuk digunakan bersama kerangka konsep perkembangan teknologi yang masih berkembang, yaitu Social Contruction of Technology (SCoT). Namun sebelum secara spesifik kita menelaah bagaimana SCoT dan Strukturasi Giddens digunakan bersama-sama, ada baiknya kita membahas Strukturasi Giddens terlebih dahulu. 
Strukturasi Giddens dan Social Construction of Technology (SCoT) Sebagai Pisau Analisis Alternatif Penelitian Sosial Atas Teknologi Media

\section{A. Perkembangan Strukturasi Giddens}

Teori strukturasi Giddens muncul sebagai hasil elaborasi dan kritik dari berbagai teori lain seperti Marxis, interaksionisme simbolik, dan fungsionalisme struktural (Ritzer \& Goodman, 2007, p.507). Giddens sebagaimana beberapa ahli lainnya seperti Fuller, Margaret Archer dan Dewe menaruh perhatian pada masalah hubungan antara agen dengan struktur (Ritzer \& Gorodman, 2007, p.505). Selama beberapa periode teori-teori sosial dihadapkan pada dua kubu yang memiliki pandangan yang saling bertentangan, yaitu kubu sosiologi interpretatif versus kubu fungsionalisme dan strukturalisme (Ritzer, 2007 \& Giddens, 1984).

Fungsionalisme dan strukturalisme cenderung mengekspresikan sudut pandang naturalistik dan menuju objektivisme. Kedua pendekatan ini menekankan keunggulan keutuhan sosial atas bagian-bagian individualnya. Dengan kata lain kehidupan sosial ditentukan oleh bingkai struktural sehingga gerak individu-individu sangat tergantung pada bingkai tersebut. Sebaliknya sosiologi interpretatif menekankan subyektivitas atau tindakan individual dengan merendahkan peran struktur. Giddens (1984) menyebutkan pendekatan sosiologi interpretatif sebagai imperialisme subyek atas obyek, sementara strukturalisme dan fungsionalisme disebutnya imperialisme obyek sosial (Giddens, 2003b, p.1-2).

Giddens (1984) menolak pendekatan kedua kubu yang menekankan telaah ilmu sosial hanya pada salah satu aspek saja, yaitu dominasi subyek individu (agensi) dihadapkan pada dominasi totalitas masyarakat (struktur). Bagi Giddens domain kajian ilmu-ilmu sosial adalah pertemuan diantara kedua kubu dalam hubungan yang dialektis. Pertemuan antara agensi dan struktur ini terwujud dalam praktek-praktek sosial yang ditata menurut ruang dan waktu dan berlangsung secara rekursif atau berulang-ulang (Giddens, 2003, p.2-3).

Gidden (1984) setuju bahwa riset sosial selalu berkaitan dengan hubungan antara tindakan (agensi) dan struktur, tetapi bukan berarti struktur yang menentukan tindakan atau sebaliknya. Teori strukturasi Giddens ini merupakan upaya paling terkenal yang mengintegrasikan agen dengan struktur (Ritzer \& Goodman, 2007, p.507). Integrasi antara agen dan struktur ini diterjemahkan Giddens dalam konsep dualitas struktur sebagai kontra bagi dualisme.

\section{B. Dualitas Struktur}

Tujuan fundamental teori strukturasi adalah menjelaskan hubungan saling memengaruhi antara agen dan struktur. Ini artinya kedua komponen tidak dapat dipahami dalam keadaan saling terpisah. Kondisi tidak terpisahkan antara agen dan struktur ini lah yang dimaksud Giddens dengan dualitas. Seluruh tindakan sosial memerlukan struktur dan seluruh struktur membutuhkan tindakan sosial (Ritzer \& Goodman, 2007, p.508). Sementara itu dalam konteks dualisme, agen dan struktur merupakan dua hal yang terpisah dan cenderung bertentangan. Dualisme agen dan 
Strukturasi Giddens dan Social Construction of Technology (SCoT) Sebagai Pisau Analisis

Alternatif Penelitian Sosial Atas Teknologi Media

Baru

struktur berarti masing-masing dapat diamati secara independen tanpa memperhatikan keterkaitan satu sama lain.

Pada konsep dualitas, tindakan-tindakan agen yang berulang-ulang akan menciptakan suatu pola atau jejak memori yang memungkinkan tersedianya kondisi dimana tindakan serupa dapat dilakukan oleh agenagen lain. Struktur dalam konsepsi Giddens itu hadir (exist) hanya dalam perwujudan melalui praktik-praktik tertentu dan sebagai jejak memori yang berorientasi pada perilaku manusia sebagai agen yang berpengetahuan (knowledgeable human agent) (Giddens, 2003, p.20-21). Struktur sebagai jejak memori dan perwujudan praktik-praktik yang berulang ini menjadi sesuatu yang membatasi (constraint) tapi sekaligus juga memungkinkan (enabler) tindakan-tindakan dikemudian hari (Giddens, 1984:25,26) dalam (Ritzer \& Goodman, 2007, p.510). Struktur disini berperan sebagai medium sekaligus hasil dari praktik sosial yang berulang dan terorganisir (Ritzer \& Goodman, 2007, p.511).

Melalui dan dalam aktivitas-aktivitas, agen-agen mereproduksi kondisi-kondisi yang memungkinkan dilakukannya aktivitas tadi (Giddens, 2003, p.3). Sebagai ilustrasi konsep tersebut, kita dapat mengambil contoh ketika individu sebagai agen melakukan aktivitas komunikasi dengan teman-temannya melalui facebook, misalnya untuk menyampaikan undangan pernikahan. Melalui tindakan itu sesungguhnya individu tadi telah mereproduksi nilai-nilai dan kondisi yang akan memungkinkan orang lain di waktu lain melakukan hal serupa, setidaknya dengan meningkatkan rasa kewajaran untuk melakukan hal yang sama. Nilai kewajaran yang digunakan orangorang secara berulang ketika menggunakan facebook untuk mengundang teman ke acara pernikahan kemudian menjadi suatu sistem budaya berkomunikasi atau dengan kata lain menjadi bagian dari praktik-praktik rekursif yang membentuk struktur budaya komunikasi. Namun perlu dicatat tindakan-tindakan agen yang dilakukan secara rekursif, walaupun dilakukan dengan kesadaran dan motivasi, seringkali menimbulkan konsekuensi yang tidak dimaksudkan (unintended consequences) (Giddens, 2003, p.6-17). Manakala agen melakukan tindakan-tindakan yang kemudian melahirkan konsekuensi tak dimaksudkan dalam bentuk produksi dan reproduksi tindakan lain dikemudian hari, maka agen melakukan tindakan keagensian sehingga agen berubah menjadi agensi.

Hubungan agen - struktur dalam strukturasi Giddens cenderung kearah hubungan agensi - struktur. Dualitas agensi-struktur ini bisa diartikan secara sederhana bahwa manusia memang memiliki kehendak dan pilihan dalam bertindak, namun kehendak dan pilihan tersebut tidak menentukan hasil yang dikeluarkan (McPhee \& Poole, 2009, p.936). Struktur sebagai sesuatu yang ada sebagai hasil praktik rekursif agen, seringkali terbentuk sebagai hasil konsekuensi yang tidak disadari, dan kemudian menjadi rules dan resources bagi tindakan-tindakan agen selanjutnya.

Struktur, kata Giddens hanya ada di dalam dan melalui aktivitas agen manusia. 
Strukturasi Giddens dan Social Construction of Technology (SCoT) Sebagai Pisau Analisis Alternatif Penelitian Sosial Atas Teknologi Media

Baru

Struktur hanya dapat terwujud karena adanya aturan (rules) dan sumber daya (resources). Fenomena sosial sebagai hasil dari praktik-praktik sosial oleh agen memiliki kapasitas yang cukup untuk menjadi struktur (Ritzer \& Goodman, 2007, p.510). Memang definisi struktur dari Giddens berbeda dari definisi yang diberikan oleh Durkheminian. Struktur berdasarkan pola Durkheminian selalu dipandang sebagai sesuatu yang ada diluar dan memaksa aktor. Giddens memang mengakui bahwa struktur dapat menjadi kekuasaan yang memaksa, namun cara pandang para sosiolog Durkheminia dianggapnya terlalu berlebihan.

\section{Waktu dan Ruang}

Waktu dan ruang menjadi variabel penting dalam teori strukturasi karena praktik-praktik sosial dilakukan dalam koridor waktu dan ruang tertentu. Lazimnya waktu dan ruang ini berkaitan dengan kehadiran orang lain saat praktik-praktik sosial tertentu dilakukan. Kehadiran ini biasanya terjadi dalam bentuk tatap muka, namun dalam kehidupan modern yang didukung oleh teknologi telah memungkinkan terbentuknya sistem sosial yang berjarak dalam arti orang lain tidak perlu hadir dalam waktu dan ruang yang sama. (Ritzer \& Goodman, 2007, p.511-512)

Media baru melalui bentuk digital, berjaringan dan terkonvergensinya dalam hal ini menjadi teknologi yang memungkinkan terjadinya praktik-praktik sosial melintasi waktu dan ruang bagi orang-orang yang terlibat di dalamnya.

\section{Kesadaran Diskursif dan Praktis}

Menjadi manusia berarti menjadi agen bertujuan yang memiliki alasan-alasan atas aktivitas-aktivitas yang dilakukan dan jika diminta akan mampu menjelaskan alasan-alasan tersebut berulang-ulang. Kemampuan menjelaskan ini termasuk juga jika si agen itu berbohong mengenai alasan-alasan yang dikemukakan (Giddens, 2003, p.3). Manusia sebagai agen dalam konteks Giddens berkesan sebagai agen yang aktif, dalam arti selalu memiliki alasan dan kesadaran dalam melakukan aktivitas-aktivitasnya.

Namun Giddens juga menjelaskan bahwa bentuk kesadaran yang dimaksud memiliki dua dimensi yaitu; kesadaran diskursif dan kesadaran praktis. Garis antara kesadaran diskursif dan praktis berfluktuasi dan dapat ditembus antara satu dan lainnya. Ini bisa kita lihat misalnya saat mengamati pengalaman agen-agen individu dalam konteks aktivitas sosial yang berbeda (Giddens, 2003, p.5)

Sebagai agen, aktor-aktor sosial biasanya akan mampu menjelaskan sebagian besar hal-hal yang mereka lakukan jika memang diminta (Giddens, 2003, p.6). Namun kita biasanya tidak akan menanyai orang lain tentang alasan dia melakukan aktivitas yang sifatnya konvensional bagi kelompok atau budaya yang dia dan kita sendiri menjadi anggotanya (Giddens, 2003, p.7).

Agen biasanya melakukan monitoring terhadap praktek sosial dan kondisi yang memungkinkan praktek sosial yang lazim dilakukan itu berlangsung. Walaupun setiap agen cenderung dapat menjelaskan secara di- 
Strukturasi Giddens dan Social Construction of Technology (SCoT) Sebagai Pisau Analisis

Alternatif Penelitian Sosial Atas Teknologi Media

Baru

skursif alasan praktek sosial yang dilakukan, jarang sekali seorang agen menanyai agen lain tentang alasan praktek sosial yang sudah menjadi konvensi (Giddens, 2003, p.7).

Sedangkan gagasan kesadaran praktis merupakan dasar bagi teori strukturasi (Giddens, 2003, p.7). Batas kesadaran praktis dengan kesadaran diskursif dapat diubah oleh banyak aspek sosialisasi dan pengalaman belajar agen. Antara kesadaran praktis dan diskursif tidak ada batasan, hanya ada perbedaan-perbedaan antara apa yang bisa dikatakan dan apa yang secara khas bisa dilakukan (Giddens, 2003, p.8).

Agen, menurut Giddens adalah aktor yang berpengetahuan dan selalu berusaha melakukan rasionalisasi atas tindakan-tindakannya. Menjadi manusia kata Giddens adalah menjadi agen yang bertujuan. Untuk itu manusia sebagai agen selalu memonitor tindakan-tindakannya melalui proses yang disebut Giddens sebagai reflexive monitoring of action atau pemantauan reflektif atas tindakan. Pada proses pemantauan reflektif ini agen menilai aspek-aspek sosial dan fisik dimana agen terlibat dalam tindakan. Hasil refleksifitas itu digunakan agen untuk melakukan rasionalisasi tindakan atau menentukan tindakan-tindakan dimasa depan.

Tindakan memiliki konsekuensi yang tidak dimaksudkan (unintended consequences). Makna agensi menurut Giddens mengacu pada kekuasaan kemampuan agen dalam melakukan tindakan, terlepas apakah hasilnya sesuai dengan maksud awal agen. Contohnya, seseorang berusaha mengangkat gelas namun malah terjatuh dan tumpah. Gelas yang jatuh dan tumpah dianggap merupakan tindakan agensi karena peristiwa itu tidak akan terjadi bila tidak ada campur tangan agen yang berusaha meraih gelas tadi. (Giddens, 2003, p.8)

\section{Social Construction of Technology (SCOT)}

\section{A. Perkembangan SCoT}

Teori atau konsep SCoT berawal dari penjelasan Trevor Pinch and Wiebe Bijker dalam, "The Social Construction of Facts and Artefacts: or How the Sociology of Science and the Sociology of Technology Might Benefit Each Other". SCoT merupakan suatu bagian penting dari kajian terhadap ilmu pengetahuan dan teknologi yang berusaha melakukan analisa teknologi sebagai hasil bentukan sosial (social shaping of technology) (Klein \& Kleinman, 2002, p.28). Sebagai bagian dari kajian Social Shapping of Technology (SST), SCoT lebih menekankan pengaruh masyarakat terhadap teknologi daripada sebaliknya, SCoT berupaya memahami hubungan yang kompleks antara masyarakat dan teknologi (Lievrouw \& Livistone, 2006c, p.246).

Konsep dasar SCoT menyatakan bahwa desain teknologi merupakan suatu proses terbuka dimana kondisi sosial selama tahap pengembangan memiliki peran dalam menentukan desain akhir. Kondisi sosial yang berbeda-beda selama proses pengembangan desain berpeluang menghasilkan desain akhir yang berbeda-beda pula. 
Strukturasi Giddens dan Social Construction of Technology (SCoT) Sebagai Pisau Analisis Alternatif Penelitian Sosial Atas Teknologi Media

Baru

"[Basic concepts of SCoT] suggests that technology design is an open process that can produce different outcomes depending on the social circumstances of development. (Klein \& Kleinman, 2002, p.29)"

Pinch \& Bijker (1984) membagi kajian teknologi (technology studies) menjadi tiga bagian, yaitu: innovation studies, history of technology, dan sociology of technology. Pendekatan innovation studies dan history of technology cenderung melihat perkembangan teknologi secara linear melalui kajian empirik terhadap teknologi yang berhasil saja. Sementara sociology of technology menawarkan suatu perspektif bahwa keberhasilan dan kegagalan suatu teknologi merupakan hasil interaksi sosial di tempat teknologi itu berkembang. Pendekatan terakhir inilah yang kemudian memberikan jalan bagi munculnya konsep SCoT (p.404-408).

Pinch dan Bijker (1984) mengembangkan SCoT berdasarkan konsep Empirical Programme of Relativism (EPoR), suatu kajian tentang perkembangan ilmu pengetahuan alam dari sudut pandang konstruksi sosial. Berdasarkan EPoR maka penjelasan mengenai penerimaan dan penolakan terhadap suatu klaim pengetahuan itu ada di dunia sosial daripada di dunia fisik (natural world) (Pinch \& Bijker, 1984, p.401). Kajian EPoR sendiri menfokuskan diri terutama pada kontroversi yang terjadi dalam pengembangan pengetahuan. EPoR menjelaskan proses pengembangan pengetahuan dalam tiga tahapan. Tahap pertama adalah fleksibilitas interpretasi (interpretative flexibility) terhadap penemuan sains, yaitu penemuan sains dapat diinterpretasikan secara berbeda oleh ilmuwan yang berbeda. Tahap kedua adalah mekanisme sosial manakala terdapat konsensus ilmiah yang digunakan sebagai acuan untuk mendefinisikan kebenaran dan membatasi interpretasi yang muncul. Tahap ketiga adalah menghubungkan mekanisme penyimpulan atau penutupan (closure mechanism) dengan konteks sosial budaya yang lebih luas (Pinch \& Bijker, 1984, p.409).

EPoR yang menjadi acuan bagi konsep SCoT berangkat dari tradisi sociology of scientific knowledge yang telah berkembang dan didukung cukup banyak kajian empiris, sementara SCoT merupakan langkah awal pendekatan empirik tradisi sociology of technology yang masih berupa embrio dan belum memiliki tradisi riset yang mapan (Pinch \& Bijker, 1984, p.410). Ini berarti pendekatan SCoT masih membuka cukup banyak ruang bagi pengembangan konsep dan kajian empirik.

Pinch \& Bijker (1984) dalam pemaparan awal SCoT mengembangkan tiga tahapan dalam EPoR menjadi empat komponen yang saling berkaitan, yaitu; relevant social group, interpretative flexibility, clousure and stabilization, dan the wider context. Keempat komponen SCoT tersebut kemudian menjadi acuan bagi sejumlah penelitian, namun sebagian besar diantaranya menggunakan pendekatan yang berpusat pada agensi (agency-centered approach) (Klein \& Kleinman, 2002, p.28). Naskah awal Pinch dan Bijker mengenai SCoT (1984) lebih banyak member- 
Strukturasi Giddens dan Social Construction of Technology (SCoT) Sebagai Pisau Analisis

Alternatif Penelitian Sosial Atas Teknologi Media

Baru

ikan penjelasan terhadap komponen interpretative flexibility serta clousure and stabilization. Sementara the wider context merupakan komponen yang paling sedikit disentuh.

Konsep awal SCoT seperti yang dikemukakan Bijker dan Pinch tersebut kemudian mendapat berbagai kritik dan respon yang mendorong munculnya varian teori. Klein \& Kleinman (2002) misalnya menilai konsep SCoT Bijker dan Pinch terlalu berpusat pada keagenan (agency-centric) dan mengabaikan peran struktur dalam keseluruhan proses. Klein \& Kleinman lalu menganjurkan untuk lebih memberikan porsi besar pada kekuatan struktur yang memengaruhi setiap proses dalam komponen-komponen SCoT.

SCoT juga kemudian menjadi landasan bagi ilmuwan lain seperti Norcliffe (2009) untuk mencetuskan konsep lanjutan. Norcliffe dalam hal ini merumuskan Geographical Construction of Technology (G-COT) yang merupakan adaptasi teori SCoT. G-COT menekankan pada interaksi antara pembuat dan pengguna dalam suatu area geografis tertentu terutama pada periode awal pengembangan artefak teknologi.

Bijkner (1995) kemudian menambahkan satu konsep tambahan berupa technological frame sebagai suatu struktur yang membatasi dan mendorong tindakan tertentu terhadap teknologi yang terkait. Tindakan Bijkner menambahkan konsep technological frame tersebut merupakan langkah penting sebagai pengakuan terhadap kontribusi struktur dalam suatu proses perkembangan teknologi, namun begitu masih banyak kemungkinan lain untuk memperkaya pemahaman terhadap peran struktur. Berbagai pihak juga telah mencoba pendekatan lain terhadap peran struktur, misalnya Kline \& Pinch (1996) menggunakan peran gender sebagai struktur dalam proses SCoT, kemudian Rosen (1993) menggunakan konteks postmodern dan post-Fordist economy sebagai struktur yang memengaruhi perkembangan teknologi. (Klein \& Kleinman, 2002, p.31).

Pendekatan SCoT dari Klein \& Kleinman yang lebih menekankan pengaruh struktur pada intinya merefleksikan asumsi dasar terhadap dunia sosial yang dibatasi struktur.

"The fundamental premise of our approach is that social world constituted of historically established structures that at any given point in time confront actors as external and constraining." (Klein \& Kleinman, 2002, p.35)

Walaupun Klein \& Kleinman mengakui bahwa struktur itu sendiri merupakan konstruksi sosial, namun keduanya menegaskan bahwa pendekatan mereka lebih menaruh perhatian terhadap pengaruh yang ditimbulkan struktur daripada mengkaji pembentukkan struktur itu sendiri. Klein \& Klienman percaya bahwa teknologi dan konteks sosial yang melingkupinya, walaupun saling membentuk tetapi masih dapat dikaji sebagai fenomena yang terpisah (Klein \& Kleinman, 2002, p.36).

Lebih jauh Klein \& Kleinman (2002) menekankan bahwa konsep awal SCoT dari Pinch \& Bijker (1984) gagal memperhitungkan ketidakseimbangan kekuasaan dalam 
Strukturasi Giddens dan Social Construction of Technology (SCoT) Sebagai Pisau Analisis Alternatif Penelitian Sosial Atas Teknologi Media

Baru

hubungan antar kelompok sosial relevan.

"SCoT assumes that groups are equal and that all relevant social groups are present in the design process. This fails to adequately attend to power asymmetry between groups. Some groups may be effectively prevented from participating in the design process at all" (Williams \& Edge, 1996) in (Klein \& Kleinman, 2002, p.31)

Perbedaan antara konsep awal SCoT (Pinch \& Bijker, 1984) dengan SCoT berpendekatan struktur (Klein \& Kleinman, 2002) sebenarnya merefleksikan dua kubu pemikiran sosial yang bersebrangan, yaitu kubu yang berorentasi individual atau agen dan kubu yang berorientasi struktur. Maka dari itu akan menarik apabila eksplorasi terhadap SCoT juga mencobakan perkembangan pemikiran sosial yang mengintegrasikan agen dengan struktur sebagai rangkaian proses yang saling membentuk seperti yang dijelaskan dalam teori strukturasi Giddens.

\section{B. Komponen SCoT}

Bijker merumuskan 4 komponen utama teori SCoT, yaitu relevant social group, interpretative flexibility, closure and stabilization, dan the wider context.

\section{a. Relevant Social Group}

Konsep kelompok sosial relevan (relevant social group) digunakan untuk mengelompokkan pihak-pihak yang relevan dengan proses pengembangan desain teknologi. Konsep ini terkait dengan konsep lain, yaitu fleksibilitas interpretatif (interpretative flexibility). Individu maupun kelompok-kelompok yang memiliki pemahaman atau makna yang serupa terhadap suatu teknologi dapat dikategorikan dalam suatu kelompok sosial relevan yang sama.

"The term is used to denote institutions and organizations (such as the military or some specific industrial company), as well as organized or unorganized groups of individuals. The key requirement is that all members of a certain social groups share the same set of meanings, attached to a specific artefact. In deciding which social groups are relevant, the first question is wheather the artefact has any meaning at all for the members of the social group under investigation. Obviously, the social group of 'consumers' or 'users' of the artefact fulfils this requirement." (Pinch \& Bijker, 1984, p.414)

Teori SCoT mengadopsi model perkembangan teknologi yang multi arah. Model tersebut memberikan ruang untuk menjelaskan mengapa sebagian varian teknologi tidak berkembang lebih jauh dan mengapa varian-varian lain dapat bertahan dan terus berkembang (Pinch \& Bijker, 1984, p.411). Varian-varian suatu teknologi muncul karena adanya perbedaan makna yang diberikan kelompok-kelompok sosial terhadap artefak teknologi. Jika kita menengok teknologi media sosial misalnya, kita dapat melihat adanya berbagai varian teknologi mulai dari email, chat, blog, wiki, microblogging, social network site dan sebagainya. Varian-varian media sosial tersebut muncul sebagai respon terha- 
Strukturasi Giddens dan Social Construction

of Technology (SCoT) Sebagai Pisau Analisis

Alternatif Penelitian Sosial Atas Teknologi Media

Baru

dap definisi dan kebutuhan berbagai kelompok sosial relevan yang bersentuhan dengan teknologi media sosial.

Terkait dengan fleksibilitas interpretasi, kelompok sosial relevan yang berbeda akan memiliki interpretasi yang berbeda pula mengenai bagaimana sebaiknya suatu artefak teknologi dibuat dan digunakan. Berbagai interpretasi yang diterjemahkan ke dalam bentuk berbagai varian artefak teknologi itu lama-kelamaan cenderung mengerucut menghasilkan varian artefak teknologi yang dapat diterima oleh mayoritas kelompok-kelompok sosial relevan. Pinch \& Bijker (1984) menunjukkan argumen tersebut melalui kajian terhadap perkembangan sepeda. Varian-varian sepeda mulai dari yang beroda satu, dua dan tiga, kemudian beroda kayu dan karet, varian ukuran roda depan sangat besar sementara roda belakang kecil versus ukuran roda sama, semua itu kemudian perlahan-lahan mencapai konsensus pada bentuk sepeda di jaman sekarang ini.

Kelompok sosial relevan memegang peran penting dalam menentukan arah perkembangan artefak teknologi. Bertahan atau tidaknya suatu varian artefak teknologi tergantung pada masalah dan solusi yang terkandung pada artefak teknologi itu bagi kelompok-kelompok sosial yang relevan.

Produser dan pengguna artefak teknologi jelas dapat dikelompokkan dalam dua kelompok sosial relevan yang berbeda. Penentuan kelompok sosial relevan semata-mata ditentukan oleh adanya makna artefak teknologi yang dimaksud bagi suatu kelompok sosial. Ini berarti penentuan kelompok sosial relevan tidak sesederhana produser dan pengguna, karena diantara sesama produser dan pengguna pun dapat berkembang makna artefak teknologi yang berbeda. Misalnya dalam kasus pengembangan komputer tablet, pada awalnya produser dari perusahaan Apple memiliki definisi kenyamanan ukuran tablet yang berbeda dibandingkan dengan Samsung dan Dell. Apple meyakini bahwa ukuran paling ideal dan nyaman adalah 10 inchi, sementara Samsung dan Dell percaya bahwa ukuran 7 dan 5 inchi pun masih nyaman untuk digunakan.

Begitu kelompok-kelompok sosial relevan berhasil diidentifikasi, kelompok-kelompok tersebut digambarkan secara lebih detail. Detail tersebut diperlukan untuk mendefinisikan fungsi artefak bagi masing-masing kelompok (Pinch \& Bijker, 1984, p.415). Contoh penggambaran kelompok sosial relevan misalnya;

"the social group of cyclist riding the high-wheeled Ordinary consisted of young men of means and nerve: they might be professional men, clerks, schoolmasters or dons'. For this social group, the function of the bicycle was primarily for sport." (Pinch \& Bijker, 1984, p.415)

Peneliti SCoT khususnya tertarik pada masalah-masalah yang dihadapi masing-masing kelompok berkaitan dengan artefak teknologi. Pada masing-masing masalah, variasi solusi dapat diidentifikasi. Masalah-masalah yang berbeda bagi masing-masing kelompok 
Strukturasi Giddens dan Social Construction of Technology (SCoT) Sebagai Pisau Analisis Alternatif Penelitian Sosial Atas Teknologi Media

Baru

sosial tersebut sering kali melahirkan konflik selama proses pengembangan artefak teknologi. Misalnya dalam kasus pengembangan sepeda terjadi konflik antara kebutuhan akan kecepatan dengan keselamatan. Ada kelompok-kelompok yang mengedepankan kecepatan, namun ada pula yang meletakkan keselamatan sebagai prioritas utama (Pinch \& Bijker, 1984, p.415). Jika kita bawa konsep tersebut pada konteks media sosial misalnya, terdapat dua kebutuhan yang saling bertentangan dan sama-sama penting, yaitu kebutuhan untuk terkoneksi dengan sebanyak mungkin orang versus kebutuhan akan privasi dan keselamatan dari penguntit digital.

Suatu skema masalah atau konflik dapat mendatangkan variasi solusi. Solusi yang muncul sebagaimana konflik yang mungkin muncul, tidak selalu merupakan isu teknologi, bisa juga berkaitan dengan isu hukum (misalnya paten) atau bahkan isu moral (misalnya perubahan cara pandang terhadap wanita bercelana panjang ketika sepeda mulai populer di kalangan wanita).

\section{b. Interpretative Flexibility}

Komponen fleksibilitas interpretasi ini pada dasarnya menyoroti bahwa interpretasi terhadap artefak teknologi bagi kelompok-kelompok sosial relevan itu fleksibel. Fleksibilitas bukan saja terjadi pada cara bagaimana orang-orang memikirkan atau menginterpretasi artefak, namun juga pada cara artefak tersebut di desain. Budaya memegang peran penting dalam pembahasan kom- ponen ini.

"In SCoT, the equivalent of the firts stage of the EPOR would seem to be the demonstration that technological artefatcs are culturally constructed and interpreted - in other words, the interpretative flexibility of technological artefact mus be shown." (Pinch \& Bijker, 1984, p.421)

Pada pendekatan SCoT yang berorientasi agen (Pinch \& Bijker) fleksibilitas ini dipandang sebagai keleluasaan agen atau individu untuk menafsirkan teknologi secara bebas walaupun disebutkan pula ada wider context yang memayungi interpretasi para agen. Pendekatan SCoT berorientasi struktur (Klien \& Klienman) menolak keleluasaan yang terlalu besar ditangan agen untuk melakukan interpretasi terhadap teknologi. Mereka berpendapat struktur di sekitar agen memiliki kekuatan yang cukup besar untuk membatasi dan mengarahkan interpretasi yang muncul.

SCoT yang menggunakan kerangka teori strukturasi mencoba pendekatan yang menengahi kedua cara pandang tadi. Di sini interpretasi agen yang diterjemahkan menjadi praktik penggunaan berulang diasumsikan akan membentuk struktur yang menjadi wider context. Struktur yang terbentuk itu lalu menyediakan aturan dan sumberdaya yang dibutuhkan agen untuk melakukan interpretasi dikemudian hari dan mengimplementasikannya dalam bentuk tindakan-tindakan penggunaan. Dengan demikian sesungguhnya proses interpretasi dan pembentukkan struktur membentuk lingkaran proses yang tak berkesudahan. 
Strukturasi Giddens dan Social Construction of Technology (SCoT) Sebagai Pisau Analisis

Alternatif Penelitian Sosial Atas Teknologi Media

Baru

\section{c. Closure and Stabilization}

Seperti telah disebutkan sebelumnya, masing-masing kelompok sosial yang terlibat dengan artefak teknologi memiliki interpretasi tersendiri mengenai artefak itu. Perbedaan interpretasi yang muncul sering menjadi masalah bagi pengembangan artefak, namun seiring waktu desain artefak teknologi akan mengalami elaborasi, sampai konflik yang berkaitan dengan artefak itu teratasi dan tidak lagi menjadi masalah bagi kelompok sosial relevan mana pun (Pinch \& Bijker, 1984). Pada tahap ini proses yang melibatkan banyak kelompok (multi-group) disebut mencapai penutupan (closure) dimana tidak ada lagi modifikasi desain lebih lanjut, dan artefak stabil dalam bentuk finalnya (Klein \& Kleinman, 2002, p.30).

Tahapan closure \& stabilization dapat dicapai melalui dua cara, yaitu; rhetorical closure dan closure by redefinition. Rhetorical closure terjadi ketika suatu deklarasi dibuat untuk menyatakan bahwa sudah tidak ada lagi problem yang terkait dengan artefak dan tidak perlu lagi ada pengembangan lebih lanjut terhadap desain artefak. Kuncinya disini adalah bagaimana meyakinkan kelompok-kelompok sosial relevan bahwa problem yang ada sudah berhasil diatasi. Pinch \& Bijker menyebutkan kampanye iklan sebagai suatu contoh upaya rhetorical closure (Pinch \& Bijker, 1984, p.427). Sedangkan closure by definition terjadi manakala masalah-masalah yang belum teratasi mengalami definisi ulang sehingga hal-hal tersebut tidak lagi dianggap merupakan masalah bagi kelompok-kelompok sosial relevan (Klein \& Kleinman, 2002, p.30).

Komponen ini ketika dibenturkan pada strukturasi Giddens menjadi sedikit problematik, karena strukturasi menekankan soal proses menstruktur yang terjadi terus menerus tiada henti sedangkan closure \& stabilization baik dalam pendekatan Pinch maupun Klien berhenti pada penjelasan adanya suatu pemaknaan dan desain yang stabil. Namun sebenarnya hal tersebut dijelaskan pula oleh Giddens melalui penjelasannya tentang struktur. Giddens mengakui kekuatan memaksa struktur terhadap perilaku agen, karena struktur dapat berfungsi sebagai pembatas (constraint) sekaligus pembuka peluang (enabler) bagi tindakan-tindakan dikemudian hari. Berdasarkan kacamata strukturasi ini proses closure \& stabilization akan selalu terjadi karena agen selalu melakukan tindakan monitoring reflektif terhadap situasi dimana aktivitas terjadi. Interpretasi dominan yang diulang terus menerus bisa saja membentuk struktur tertentu. Namun selain membatasi, struktur yang terbentuk itu juga membuka peluang bagi munculnya interpretasi-interpretasi baru.

\section{d. The Wider Context}

Pinch dan Bijker telah mendeteksi adanya kontribusi situasi sosiokultur (sociocultural) dan politik di sekitar kelompok sosial dalam pembentukan norma dan nilai-nilai yang dianut oleh kelompok sosial itu. Pada akhirnya norma dan nilai-nilai yang dianut suatu kelompok sosial akan memengaruhi makna yang diberikan oleh kelompok sosial 
Strukturasi Giddens dan Social Construction of Technology (SCoT) Sebagai Pisau Analisis Alternatif Penelitian Sosial Atas Teknologi Media

itu terhadap artefak teknologi yang dihadapinya (Pinch \& Bijker, 1984, p.428). Namun demikian naskah pertama tentang SCoT belum menjelaskan banyak tentang bagaimana aspek sosial, budaya dan politik memengaruhi atau memberikan kontribusi dalam proses fleksibilitas interpretasi dan penyetabilan.

\section{SCoT Dalam Kerangka}

\section{Strukturasi}

Kajian teknologi dengan menggunakan SCoT sejauh ini telah menggunakan perspektif yang mengutamakan agen (Pinch \& Bijker) lalu kemudian mendapatkan kritik karena mengabaikan pengaruh struktur. Klein dan Kleinman mengajukan perspektif yang mengedepankan pengaruh struktur dalam pembentukan kelompok sosial, interpretasi terhadap teknologi dan kemudian proses kesepakatan dan penyetabilan. Dua pendekatan tersebut sebenarnya mewakili pergulatan antara perspektif sosiologi interpretatif dan strukturalisme.

Giddens muncul dengan mencoba memberikan jalan tengah dalam menyikapi pertentangan antara kedua perspektif tadi. Giddens mengajukan teori strukturasi yang berusaha menjelaskan bahwa agensi dan struktur harus dilihat sebagai hubungan dialektis yang saling membentuk. Mengikuti perkembangan pemikiran tersebut maka penulis mencoba menawarkan perspektif dialektis antara agensi dengan struktur untuk menjelaskan proses-proses yang terjadi dalam konsep Social Construction of Technology. Ini dapat dilaku- kan karena Pinch dan Bijkner (1984) sendiri mengakui bahwa konsep SCoT masih seperti embrio yang memerlukan banyak penelitian empirik untuk mematangkannya. Penggunaan SCoT dalam berbagai penelitian menurut Pinch dan Bijkner sebaiknya dipandang sebagai suatu kerangka konsep yang fleksibel bukannya dijadikan kerangka pemikiran yang diikuti sebagaimana adanya (Pinch \& Bijker, 1984, p.33)

Ilustrasi yang bisa menggambarkan bagaimana SCoT digunakan bersama dengan teori strukturasi misalnya dapat dilihat pada penelitian tentang penggunaan media sosial dikaitkan dengan budaya komunikasi (Octavianto, 2011). Pada penelitian tersebut pengguna media sosial diposisikan sebagai agen-agen berpengetahuan yang berkehendak bebas, namun pola penggunaan media sosial yang berulang-ulang diasumsikan akan membentuk struktur yang melibatkan nilai-nilai yang berkenaan dengan budaya komunikasi. Sebaliknya praktik-praktik penggunaan media sosial untuk kepentingan komunikasi dan interaksi dibatasi pula oleh nilai, norma, dan sumber daya yang mengatur pola komunikasi antar individu yang telah menjadi struktur. Budaya komunikasi disini menjadi struktur yang memberikan peluang sekaligus membatasi tindak komunikasi yang melibatkan penggunaan media sosial.

Pada komponen kelompok sosial relevan dan fleksibilitas interpretasi misalnya, seseorang atau sekelompok orang akan menempatkan diri baik secara sadar maupun tidak pada posisi tertentu terhadap penggunaan 
Strukturasi Giddens dan Social Construction of Technology (SCoT) Sebagai Pisau Analisis

Alternatif Penelitian Sosial Atas Teknologi Media

Baru

media sosial. Penempatan posisi demikian ini akan tergantung pada interpretasi makna yang dibangun terhadap media sosial dan fungsinya bagi orang itu. Interpretasi pada awalnya berkesan bebas, namun sesungguhnya dibentuk berdasarkan struktur makna yang mewadahi praktik-praktik penggunaan media sosial tersebut. Misalnya, jika budaya komunikasi yang ada disekitar orang itu mendorong untuk mengutamaan tatap muka dalam aktivitas komunikasi, maka ada kemungkinan individu tersebut tidak menjadikan media sosial sebagai saluran utama dalam bertukar pesan.

Namun suatu interpretasi awal yang dimiliki seseorang mungkin saja berubah seiring dengan situasi-situasi yang dihadapi dalam konteks ruang dan waktu. Orang-orang disekitar individu tersebut juga melakukan praktik-praktik pengunaan media sosial yang bervariasi. Ada yang serupa namun ada pula yang berbeda dengan dirinya. Maka dari itu menarik untuk mengamati bagaimana praktik-praktik sosial berupa penggunaan teknologi media sosial yang berulang disekitar individu membentuk suatu struktur budaya komunikasi, sementara itu budaya komunikasi yang telah ada pun ikut berperan mengarahkan bagaimana individu melakukan interpretasi terhadap teknologi dan mengejewantahkannya dalam wujud praktik-praktik sosial.

Manakala seseorang melakukan interpretasi terhadap teknologi atau melakukan kompromi pemaknaan tertentu suatu teknologi dan menerapkannya dalam wujud praktek-praktek social, bisa saja dia memiliki kemampuan untuk menjelaskan alasan-alasan dibalik tindakan itu, namun ada pula sebagian tindakan yang begitu saja dilakukan tanpa mampu merumuskan penjelasannya dalam kata-kata. Fenomena-fenomena inilah yang dicari untuk mengidentifikikasikan adanya kesadaran diskursif dan praktis dalam proses fleksibilitas interpretasi dan stabilitas makna teknologi.

Terakhir, wider context dalam konsep SCoT diterjemahkan menjadi struktur sosial yang membatasi sekaligus memungkinkan berlangsungnya praktik-praktik penggunaan teknologi media sosial. Praktik-praktik tersebut menggambarkan adanya suatu interpretasi makna terhadap media sosial. Adapun struktur sebagai wider context pada penelitian tersebut dibatasi dalam konteks budaya komunikasi. Struktur budaya komunikasi disini mengandung arti sejumlah aturan dan sumber daya yang diantaranya berupa norma, aturan dan kebiasaan berkomunikasi yang berulang-ulang dipertahankan untuk memungkinkan tindakan sosial tertentu berkaitan dengan penggunaan media sosial sebagai perangkat komunikasi dan interaksi.

\section{DAFTAR PUSTAKA}

Bain, R. (1937). Technology And State Goverment. American Sociological Reviews, 2(6), 860-874.

Brodjonegoro, S. S. (2006). Konstruksi Sosial Media Baru Dan Budaya Komunikasi: Penggunaan Telpon Genggam pada Remaja Millennial. Jurnal Thesis, $V(3), 111-132$.

Djik, J. v. (2006). The Network Society (2nd ed.). London, Thousand Oaks, New Delhi: SAGE Publications.

Flew, T. (2005). New Media - an Introduction 
Strukturasi Giddens dan Social Construction of Technology (SCoT) Sebagai Pisau Analisis Alternatif Penelitian Sosial Atas Teknologi Media

Baru

(2nd ed.). Oxford, New York: Oxford University Press

Giddens, A. (2003). The Constitution of Society : Teori Strukturasi untuk Analisis Sosial (D. A. L. Sujono, Trans.). Pasuruan: Penerbit Pedati.

Hollingshead, A. B., \& Contractor, N. S. (2006). New Media and Small Group Organizing. In L. A. Lievrouw \& S. Livistone (Eds.), The Hanbook of New Media Updates Student Edition (Student Ed ed., pp. 114 - 133). London, Thousand Oaks, New delhi: SAGE Publications.

Klein, H. K., \& Kleinman, D. L. (2002). The Social Construction of Technology: Structural Considerations. Science, Technology \& Human values, 27(1), 28-52.

Krug, G. (2005). Communication, Technology and Cultural Change (1st ed.). London, Thousand Oaks, New Delhi: SAGE Publications.

Lievrouw, L. A., \& Livistone, S. (2006a). Introduction to the First Edition (2002) The Social Shaping and Consequences of ICT. In L. A. Lievrouw \& S. Livistone (Eds.), The Hanbook of New Media Updates Student Edition (Student Ed ed., pp. $x x+475)$. London, Thousand Oaks, New delhi: SAGE Publications.

Lievrouw, L. A., \& Livistone, S. (2006b). Introduction to the Updated Student Edition. In L. A. Lievrouw \& S. Livistone (Eds.), The Hanbook of New Media Updates Student Edition (Student Ed ed., pp. $x x+475)$. London, Thousand Oaks, New delhi: SAGE Publications.

Lievrouw, L. A., \& Livistone, S. (Eds.). (2006c). The Handbook of New Media (updates student edition) (student edition ed.). London, California, New Delhi: Sage Publications Ltd.
Press.

McPhee, R. D., \& Poole, M. S. (Eds.). (2009) Encyclopedia of Communication Theory (Vols. 2). Thousand Oaks, California: SAGE.

NorCliffe, G. (2009). G-COT: The Geographical Construction of Technology. Science, Technology \& Human Values, 34(4), 449-475.

Octavianto. Adi W. (2011). Media Sosial dan Budaya Komunikasi - Studi Kasus Terhadap Penggunaan Media Sosial Oleh Generasi Digital. Universitas Indonesia, Jakarta

Pinch, T. J., \& Bijker, W. E. (1984). The Social Construction of Facts and Artefacts: or How the Sociology of Science and Sociology of Technology might Benefit Each Other. Social Studies of Science, 14, 399-441.

Ritzer, G., \& Goodman, D. J. (2007). Teori Sosiologi Modern (Alimandan, Trans. 6 ed.). Jakarta: Kencana Prenada Media Group

Rogers, E. M. (1986). Communication Technology: The New Media in Society. London: The Free Press A Division oc Macmilan, Inc. 